\title{
Implementation of the Marrakesh Treaty for Visually Impaired Persons into the Chinese Copyright Law
}

Jerry Jie Hua ${ }^{*}$

On June 27, 2013, the World Intellectual Property Organization adopted the Marrakesh Treaty to Facilitate Access to Published Works for Persons who are Blind, Visually Impaired, or otherwise Print Disabled in its efforts to resolve the global book famine of visually impaired persons by providing a series of copyright exceptions that facilitate access of the visually impaired to copyright works. As a member country of the WIPO, China signed but has not ratified the Marrakesh Treaty. However, it is important that China implement the treaty provisions into its copyright law before submitting ratification to the WIPO. Chinese lawmakers are thus advised to incorporate provisions of the Marrakesh Treaty into the national copyright legislations. This article analyzes the reasons for the global book famine of the visually impaired, examines the key provisions in the Marrakesh Treaty, and provides recommendations to incorporate the provisions of the Marrakesh Treaty into the Chinese copyright laws and regulations.

Keywords: Marrakesh Treaty, WIPO, VIPs, Chinese Copyright Law

* Assistant Professor at Tongji University School of Law, Shanghai. LL.B.(China Foreign Affairs U.), LL.M. (U. Florida), Ph.D. (UHK). ORCID: http://orcid.org/0000-0002-3419-5921. This paper is part of the research project, "Construction of Copyright Limitations and Exceptions in the Digital Network Era" funded by the Ministry of Justice of the People's Republic of China (15SFB3023). The author may be contacted at: jerryhua@tongji.edu.cn / Address: Zonghe Bd. Tongji Univ., 1239 Siping Rd., Yangpu District, Shanghai 200092 P.R. China. 


\section{INTRODUCTION}

Today, advanced digital technology allows access, management, dissemination, and utilization of copyrighted information and works. In spite of such technological progress, these works are not accessible to a large number of visually impaired persons ("VIPs") mainly because there are no exceptions in national copyright laws allowing them access to copyright works at a nominal or no cost. The World Health Organization ("WHO") estimates that there are approximately 285 million VIPs worldwide and about 90 percent live in low-income settings. ${ }^{1}$ Less than 5 percent of the books are published in accessible formats for these VIPs. ${ }^{2}$ Among the 186 member States of the World Intellectual Property Organization ("WIPO"), in 2006, only 57 countries provided specific exceptions to facilitate access for VIPs to copyright works. ${ }^{3}$ The lack of an accessible format for VIPs has been dubbed as the "global book famine."

On June 27, 2013, the WIPO adopted the Marrakesh Treaty to Facilitate Access to Published Works for Persons Who are Blind, Visually Impaired, or otherwise Print Disabled (hereinafter Marrakesh Treaty) in an efforts to resolve this situation. As a part of the international copyright treaties administered by the WIPO ${ }^{5}$ it recently brought into force after ratification by Canada, the twentieth country to accede to the treaty. Given that China has been amending its Copyright Law, Chinese lawmakers are advised to incorporate provisions of the Marrakesh Treaty into the national copyright legislations prior to submitting its ratification to the WIPO.

The primary purpose of this research is to make recommendations to incorporate the provisions of the Marrakesh Treaty into the Chinese copyright laws and regulations. This paper is composed of five parts including a short Introduction and Conclusion. Part two will discuss existing problems of inadequate access to copyright works for technical, financial, and legal reasons. Part three will carry out a detailed analysis of the Marrakesh Treaty provisions to determine the benefits of the treaty to VIPs. Part four will examine exceptions provided for VIPs by the Copyright Law of the People's Republic of China, existing problems and its implementation into China's domestic copyright system. 


\section{InAdequate ACCESS FOR Visually IMPAIRED Persons to Copyright Works}

VIPs lack of access to copyright works primarily due to technical, financial, and legal factors. Technically, more copyright owners are adopting technological protection measures to control access and use of their works, leading to difficulties for VIPs in accessing protected works. Financially, publishers do not view the book market for VIPs as profitable; they are reluctant to publish works in accessible formats. Legally, the current copyright regime lacks adequate limitations and exceptions for users to adapt and transform works into accessible formats and disseminate transformed works across national borders. The overriding influence of contracts in domestic laws further prevents the access of VIPs to copyright works.

\section{A. Emergence of Technological Protection Measures and Anti-Circumvention Rules}

Digital technology has not only enabled reproduction and dissemination of works in ordinary digital format, but has also widened the scope of accessible formats for VIPs from conventional forms such as Braille, large print, or audio, to the forms of electronic Braille. Platforms, such as the Bookshare library launched by Benetech helps persons with print disability to access a broader range of scanned books online. ${ }^{6}$ Despite the new forms of books, technological progress has increased the capability of copyright owners to prevent unauthorized access and use of their works. Technological protection measures are thus widely adopted to control access to and prevent copying of works.

Encouraged by the US, the WIPO adopted the WIPO Copyright Treaty ("WCT") and the WIPO Performances and Phonograms Treaty ("WPPT") in 2006 which require member States to provide copyright owners with "adequate legal protection and effective legal remedies against the circumvention of effective technological measures that are used by authors in connection with the exercise of their rights .... and that restrict acts, in respect of their works, which are not authorized by the authors concerned" for protecting the copyright of their works. ${ }^{7}$ These were adopted by many WIPO member States, incorporated into their domestic copyright systems, and implemented to prohibit unauthorized 
circumvention of technological measures and trafficking of circumvention technologies or devices. ${ }^{8}$ However, the emergence of technological measures and a wide adoption of anti-circumvention rules by the WIPO member States have in turn reduced the access to protected works by VIPs. Although some countries have incorporated specific exceptions for circumventing technological measures, this cannot take place if the user does not have related or adequate knowledge or skills, as trafficking of circumvention technologies and devices is prohibited. Further, copyright owners are unlikely to voluntarily provide measures facilitating these exceptions. Even if the provision for appropriate measures to support VIPs are mandatory obligations imposed onto copyright owners to allow for limitations and exceptions for beneficiaries so that they can legally gain access to the works (which is the case in certain countries such as Estonia and Lithuania), ${ }^{10}$ copyright owners often decide to forego providing such measures since their obligations are not specified and there are no remedies for failure to do so. Therefore, the adoption of technological measures by copyright owners and the implementation of anticircumvention rules by a large number of countries serve to exacerbate the access problem. ${ }^{11}$

\section{B. Market Failure of Works in Accessible Format for Visually Impaired Persons}

Finances are a significant factor affecting how authors and copyright owners publish and distribute copyright works. Authors and copyright owners are interested in publishing and distributing their works in a more profitable market. However, in their view, the book market for an accessible format for VIPs is not profitable itself because production costs are higher than that for ordinary format books. ${ }^{12}$ Such high costs would discourage the publishing industry from engaging in producing accessible formats for VIPs who often have a paucity of finances themselves. Eventually, related materials are published by non-profit or governmental organizations. However, they can only provide some accessible format materials due to limited resources. This market failure is the cause of the book famine.

\section{Inadequate Copyright Exceptions for VIPs}

Prior to the Marrakesh Treaty, international copyright treaties and conventions 
did not particularly stipulate exceptions for VIPs or other disabled individuals. The primary clause for exceptions in most international copyright treaties is the three-step test of the Agreement on Trade-Related Aspects of Intellectual Property Rights ("TRIPS") under which exceptions are applicable only in "certain special cases which do not conflict with a normal exploitation of the work and do not unreasonably prejudice the legitimate interests of the right holder."13

The three-step test outlines the scope within which member States can establish exceptions for VIPs. First, the conditions in the three-step test are cumulatively applied, i.e., a qualified exception must satisfy all three conditions in the clause. The first prong stipulates the permission for producing accessible works "in certain special cases," which requires exceptions in national laws to be known, specific and narrow in scope. The second prong requires that the production "does not conflict with a normal exploitation of the work." It means the use cannot be economically competitive in that the right holders normally extract economic value from their works. ${ }^{14}$ The third prong indicates that the exception should "not unreasonably prejudice the legitimate interests of the right holder" which could be violated if an exception causes or has the potential to cause an unreasonable loss of income to the copyright owner. ${ }^{15}$

Second, when examining the exceptions for VIPs under the three-step test, it is difficult to ensure that the exceptions will satisfy all three conditions. The first prong is unlikely to pose hurdle as the exceptions will be narrow in scope. However, the second and third prongs are problematic since they require neither potential economic competitiveness, nor potential loss of income of the right holder. It is not certain that exceptions allowing non-profit or governmental organizations to reproduce works in accessible formats without charge to VIPs will not cause potential economic loss to the right holders of the copyright works.

The cumulative requirement of all three conditions in the test therefore cannot adequately address the exceptions for VIPs. In order to transform copyright works into accessible formats for VIPs, the producers need to obtain the right of adaption or derivative work from the copyright owners. This is either in the form of a license from the copyright owners, or authorization given by statutory exceptions to transform the format of the original works. On the one hand, authors or copyright owners are unlikely to voluntarily license the right of adaption to a third person or provide a derivative work right to the producers; it would contribute to 
the market failure of accessible format works for VIPs. On the other hand, because of the inadequately addressed exceptions in treaties and in domestic legislations, it is problematic for non-profit or governmental organizations to reproduce the works into accessible formats without infringing on the copyright of the right holder. ${ }^{16}$

\section{Overriding Contracts}

Without sufficient exceptions for VIPs, copyright owners are free to use contractual terms to limit transformation of their works into accessible formats for VIPs. This is true especially in the digital environment, where copyright owners largely adopt digital rights management to control the use of their works in digital format. Under digital rights management, only users who comply with the binding contractual terms are allowed to adapt the works into accessible formats. If the contract has provisions that overrides statutory exceptions to copyright, non-profit or governmental organizations are notwithstanding prohibited to produce accessible format versions even if this falls within the scope of statutory exceptions to copyright work. ${ }^{17}$

The overriding effect of binding contracts in many countries is ambiguous. In China, laws and judgments do not explicitly stipulate the relationship between copyright and contract laws, although Article 52(5) of the Contract Law lists the circumstances under which a contract will be deemed invalid, i.e., the violation of compulsory provisions in laws and administrative regulations. Compulsory provisions include effective norms and the administrative nature of norms. According to the PRC's Supreme People's Court, a contract can only be invalidated with the violation of effective norms. ${ }^{18}$ Since copyright exceptions in Chinese laws and regulations do not contain effective norms, it is assumed that a binding contract in China override copyright exceptions.

The overriding effect is even more pronounced in the digital environment, as many hardcopy works are digitalized and available on online databases in which copyright owners are able to use shrink-wrap licenses to impose binding contractual terms on their potential use. Exceptions originally allowed by law are thus excluded through shrink-wrap licensing. 


\section{The Marrakesh Treaty for VIPs}

The Marrakesh Treaty aims to facilitate access to works in accessible formats for VIPs with the production and dissemination of copyright works. It obliges the contracting parties to allow for exceptions in the treaty of their domestic laws to permit the distribution of such works both within national boundaries and across national borders. ${ }^{19}$

\section{A. Beneficiaries of Accessible Format Works}

Article 3 of the Marrakesh Treaty defines a beneficiary of accessible format works as "a person who:

(a) is blind;

(b) has a visual impairment or a perceptual or reading disability which cannot be improved to give visual function substantially equivalent to that of a person who has no such impairment or disability and so is unable to read printed works... or

(c) is otherwise unable, through physical disability, to hold or manipulate a book or to focus or move the eyes to the extent that would be normally acceptable for reading."

The scope of the beneficiaries in the treaty contains not only the blind or visually impaired, but those who cannot read print books due to a physical disability. Article 3(b) further explains that visual impairment that cannot be rectified does not require the "use of all possible medical diagnostic procedures and treatments." ${ }^{20}$ Therefore, individuals who suffer from cataract also fall within the defined scope of beneficiary persons despite that cataracts can be removed through surgery.

In addition, the Marrakesh Treaty provides a widely defined scope of accessible formats in which published work can be converted into. Accessible formats may be defined as:

a copy of a work in an alternative manner or form which gives a beneficiary person access to the work, including to permit the person to have access as feasibly and comfortably as a person without visual impairment or other print 
disability. The accessible format copy is used exclusively by beneficiary persons and it must respect the integrity of the original work ...

However, the treaty does not list the formats in detail in which the works can be converted into, but rather is accommodating all possible formats accessible to the beneficiaries. The text "used exclusively by beneficiary persons" refers to those who are actually using the accessible format and limits the conversion of the format of accessible copies permitted by the treaty. ${ }^{22}$ Therefore, contracting parties can prohibit adaptations in formats not only accessible to the beneficiaries, but also those without a visual or print disability. Integrity of the original work is always respected in this case. Changes are permitted only to make a work accessible in an alternative format. ${ }^{23}$

\title{
B. Authorized Entity
}

The Marrakesh Treaty defines the authorized entity as

\begin{abstract}
"an entity that is authorized or recognized by the government to provide education, instructional training, adaptive reading or information access to beneficiary persons on a non-profit basis," including a "government institution or non-profit organization that provides the same services to beneficiary persons as one of its primary activities or institutional obligations. ${ }^{, 24}$
\end{abstract}

According to the agreed statement concerning Article 2(c), the entities recognized by the government include those receiving financial support from the government to provide services for "beneficiary" persons. ${ }^{25}$ Therefore, a specialized agency providing services for VIPs, and a general library with institutional obligations promoting access of VIPs to copyright works, both qualify as authorized entities. ${ }^{26}$

The Marrakesh Treaty further indicates that an authorized entity establishes and follows their own practices: (i) to establish that the persons it serves are beneficiary persons; (ii) to serve only beneficiaries and unauthorized entities; (iii) to discourage the reproduction, distribution, and availability of unauthorized copies; and (iv) to maintain due care in handling the copies of works, while respecting the privacy of beneficiary persons. ${ }^{27}$ Although these four practices are not included in the definition of an 'authorized entity,' they could be considered as requirements of an authorized entity in order to have copyright exceptions under 
the treaty.

\section{Works under Exceptions}

The Marrakesh Treaty stipulates that works permitted to be converted into accessible format include "literary and artistic works within the meaning of ... the Berne Convention ..., in the form of text, notation and/or related illustrations, whether published or otherwise made publicly available in any media." 28 The agreed statement in Article 2(a) further interprets this definition as including "works in audio form, such as audiobooks." 29 The treaty thus excludes audiovisual works, such as films, for conversion into accessible format.

Inclusion of audiovisual works as an exception was discussed in the negotiation process of the Marrakesh Treaty, without reaching an agreement between developed and developing countries. Both the US and the EU are opposed to include this exception, because VIPs and people with print disability are able to listen to audiovisual works just like those without print disability. Therefore, they maintain that copyright exceptions should not apply to audiovisual works. However, China contends that works with copyright exceptions should not be confined to text, notations and/or illustrations, but should include all those categories listed under the Berne Convention, including audiovisual works. ${ }^{31}$ Although individuals with visual or print disability can listen to dialogue, sound and music in audiovisual work, they cannot make out actions, facial expressions and mood of the characters and other visual scenes merely through auditory sense. In order to facilitate people with visual and print disability to completely enjoy audiovisual work, it is necessary to convert an audiovisual work into an audio comments version and explanation about the subtleties.

In response to the conflicts between developed and developing countries on the exceptions, the Marrakesh Treaty added a "development provision" as Article 12, allowing implementation of "other copyright limitations and exceptions for the benefit of beneficiary persons than are provided by this Treaty"; which takes into consideration economic situations, social and cultural needs, and international rights and obligations of the contracting party. In other words, a contracting party may expand the scope of the works that fall under the exceptions to include audiovisual works in its domestic law.

Works with copyright exceptions should be published or be made available 
to the public. Otherwise, publication in an accessible format will be an exclusive right for the copyright owner. Although some countries, such as Australia and New Zealand, have applied the commercial availability test to examine applicability of their copyright exceptions, the Marrakesh Treaty does not oblige contracting parties to apply the test to their national laws. Under the commercial availability test, before fulfilling the request for copyright exceptions to beneficiary persons, an authorized entity must determine whether the work is commercially available in the format required by the beneficiary. ${ }^{32}$ The authorized entity must make reasonable efforts within a reasonable period of time to determine whether accessible formats are found in the national market. ${ }^{33}$ The Marrakesh Treaty provides flexibility for contracting parties to decide whether to incorporate the commercial availability test into their national laws. ${ }^{34}$ The treaty does not mandate the application of the commercial availability test due to the cross-border transfer of accessible format copies. ${ }^{35}$ Accessible format copies cannot otherwise be exported if the copies are commercially available in the market of the import country. However, it is not feasible to ask authorized entities in the exporting country to investigate commercial availability of the accessible format works within a reasonable period of time.

\section{Permitted Domestic Activities under Exceptions}

Article 4(1) of the Marrakesh Treaty obliges contracting parties to provide, in their national laws, a limitation or exception to the rights of reproduction, distribution, making the works available to the public, and public performance to facilitate the availability of the works in accessible format copies for beneficiary persons. The right of public performance is in circumstances where the literary work is recited, such as reading a poem in public. ${ }^{36}$ The treaty provides sufficient leeway for the contracting parties to adopt exceptions in their national laws. ${ }^{37}$ Therefore, whether other exclusive rights, such as the rights relating to translation and adaptation, shall be included in the copyright limitations and exceptions would be the decision of the contracting parties, as developed and developing countries have different viewpoint with regard to the issue.

Developed countries appear reluctant to allow the rights of translation and adaptation to the disabled because individuals without disability can only access the translated work if the copyright owner provides authorization. On the contrary, 
developing countries that have a diversity of local languages, such as India, support the translation of English works into local languages so as to enhance education opportunities for those who are visually disabled. ${ }^{38}$ Nigeria, Mexico, and China agree that copyright exceptions should apply to the right to adapt, as certain works need to be tailored for VIPs with different levels of education or less education to better understand the works. ${ }^{39}$

Article 4(2) of the Marrakesh Treaty provides two acts as examples that comply with Article 4(1). First, an authorized entity shall make an accessible format copy of a work, or obtain from another authorized entity an accessible format copy, and supply copies to beneficiary persons by any means as long as four conditions are met: (i) the authorized entity that is the source of the copy has lawful access to the work; (ii) the work is converted to an accessible format copy, but does not introduce changes other than those needed to make the work accessible to the beneficiary person; (iii) the accessible format copies are supplied exclusively to be used by beneficiary persons; and (iv) the activity is undertaken on a non-profit basis. ${ }^{40}$ Second, a beneficiary person or someone acting on his/her behalf may make an accessible format copy of a work for the personal use of the beneficiary person where $\mathrm{s} / \mathrm{he}$ has lawful access to the work. ${ }^{41}$

Whether these limitations or exceptions are subject to remuneration is determined by the contracting parties as a matter of national law. ${ }^{42}$ In other words, a contracting party is free to adopt a statutory license or allow absolute exceptions with respect to the permitted activities.

\section{E. Export and Import of Accessible Format Copies}

In addition to permitted domestic activities, the Marrakesh Treaty also addresses cross-border exchange of accessible format copies. Article 5 of the treaty allows an accessible format copy made under copyright limitations or exceptions to be distributed or made available to a beneficiary person or an authorized entity of another contracting party, as long as the originating authorized entity does not know, or have reasonable grounds to know that the accessible format copy would be used by other people aside from the beneficiary persons. ${ }^{43}$ Article 5(2) further interprets that, under the circumstance that the accessible format copy is distributed to a beneficiary person in another contracting party, the originating authorized entity may apply further measures to confirm the beneficiary status of 
the person that it is serving. ${ }^{44}$ However, it is likely that the accessible format copy will be used by others aside from the beneficiary. Similar to the flexibility allowed in permitted activities at the national level, the treaty also permits contracting parties to provide other limitations or exceptions in their national laws to address the export issues of accessible format copies. ${ }^{45}$

Article 6 of the treaty contains a provision that addresses the issue of importing accessible format material, functioning parallel to Article 5. Article 6 requires that a contracting party permit a beneficiary, or someone acting on the beneficiary's behalf, or an authorized entity to import an accessible format copy for the beneficiary person if $\mathrm{s} / \mathrm{he}$, his/her caretaker or the authorized entity is permitted to make an accessible format copy of a work under the stipulated limitations or exceptions. Therefore, if a contracting party only permits an authorized entity to make an accessible format copy of a work, only the authorized entity is allowed to import an accessible format work from another contracting party. The agreed statement concerning Article 6 provides room for the contracting parties to incorporate the commercial availability test or a remuneration requirement into their national laws on the import of accessible format copies. ${ }^{46}$

\section{F. Circumvention of Technological Protection Measures}

The Marrakesh Treaty encourages contracting parties to provide adequate legal protection and effective legal remedies against the circumvention of effective technological measures that are used by authors in connection with the exercise of their rights. ${ }^{47}$ It also emphasizes that the requirement under the anti-circumvention law should not prevent beneficiary persons from accessing limitations and exceptions provided in this treaty. ${ }^{48}$ The exception provision allowing circumvention of technological measures guarantees that the adoption of technological measures of copyright owners will not inhibit the production and distribution of accessible format copies for the benefit of people with visual and print disabilities. $^{49}$

According to Article 7, authorized entities may continue to apply technological measures in making and distributing accessible format copies, and making them available in accordance with their national law. ${ }^{50}$ 


\section{IMPLEMENTATION OF THE MARRAKESH Treaty In ChIna}

\section{A. Chinese Practice}

As of February 2017, China has signed, but has not ratified the Marrakesh Treaty yet. Prior to ratification, China should consider adopting the provisions of the treaty into its copyright laws and regulations. Copyright limitations and exceptions are already included in China's law and regulations. E.g., Article 22 of the Chinese Copyright Law lists 12 exceptions under which users do not have to obtain authorization from copyright owners to use the work and to pay remuneration. One exception is the transliteration of a published work into Braille and publication of the work so transliterated. ${ }^{51}$ The Implementing Regulation of the Copyright Law further provides that use of a published work without obtaining authorization from the copyright owner: (1) should comply with the Copyright Law; (2) does not conflict with the normal exploitation of the work; and (3) does not unreasonably prejudice legitimate interests of the right owner. ${ }^{52}$ The three-step test has been evidently incorporated into the Implementing Regulation of the Copyright Law so that it does not allow flexibility for judges to use their discretion in ruling the various uses on a case by case basis.

The Regulation on the Protection of the Right to Network Dissemination of Information of China (hereinafter The Regulation) extends copyright limitations and exceptions to the digital network environment. One of the exceptions is to supply published literary work to the blind through a means that is perceptible to them and not for profit. ${ }^{53}$ In this way, literary work disseminated through the information network does not require authorization from the copyright owner or remuneration from users.

China initiated the third amendment to the Copyright Law in 2012. The Draft Amendment was then sent to the Legislative Affairs Office of the State Council for review and finalization in June 2014. Article 43 of the Draft Amendment maintains most of the exceptions under the current law with minor changes. The exception for the transliteration of published work into Braille and publication of the work so transliterated remains in the Draft Amendment. Furthermore, the Draft Amendment intends to incorporate flexibility into the exceptions by listing "other circumstances" as fallback options aside from the 12 exceptions, and adding the 
three-step test as a condition to restrict these 13 listed exceptions. As long as the use of a copyright work satisfies the three-step test, it will fall within the scope of the copyright exceptions. In this case, no authorization from the copyright owner is required and no compensation shall be paid to the copyright owner.

If the Draft Amendment is finalized, more copyright exceptions with more flexibility will apply to the use of copyright works benefitting people with visual and other disabilities. If exceptions are flexible and based on the three-step test, as mentioned earlier, they still limit the supply and adequate access of copyright works to visually and print disabled individuals, since the three-step test is cumulative; the last conditions focus on potential, and not actual, loss of benefits of copyright holders. Therefore, it is important to incorporate detailed provisions on copyright exceptions for VIPs. Detailed provisions are also more feasible for the relevant entities and persons for using and distributing copyright works on the one hand, and resolve the problem of inadequate access to copyright works of VIPs on the other.

\section{B. Beneficiary Persons and Accessible Format Copy}

Copyright law and regulations in China only provide exceptions for the blind. However, the Marrakesh Treaty defines the beneficiary persons as including individuals with visual impairment or perceptual or reading disability who are not completely blind, and persons who are physically incapable of holding or manipulating a book or move their eyes for reading. ${ }^{54}$ E.g., a disabled person with normal vision falls within the defined scope of beneficiary persons under the Marrakesh Treaty, ${ }^{55}$ despite not being permitted under the exceptions for the blind in the Chinese Copyright Law in the conversion of printed work into audiobooks without authorization of the copyright owner. Given that it is easier for the disabled individual to press the button on a recorder than turn the pages of a book with his/her artificial limbs, the parameters of beneficiary persons under the Chinese Copyright Law should be expanded to include disabled persons who have visual, perceptual or reading disability or who are unable to physically hold a book or move their eyes for reading, so as to comply with the Marrakesh Treaty.

The Marrakesh Treaty provides a broad definition for "accessible format copy" allowing works to be produced in any alternative manner or form which would facilitate the access of a beneficiary person to the work. ${ }^{56}$ Accessible format copies 
in terms of the Chinese Copyright Law only include Braille and means that are perceptible only to the blind. According to the lawmakers of the Regulation, the "specific means that are perceptible to the blind" refers to reading that can only be perceived by those who are blind, such as Braille in convex and concave forms embossed by special printers. ${ }^{57}$ This narrow definition of an accessible format copy thus excludes other forms that would benefit people with visual impairment and print disability, such as large print, audiobooks, electronic books, etc. In addition, Chinese Copyright Law should consider widening the defined scope of accessible format copy to include alternative forms that would facilitate beneficiaries in gaining access to copyright works as feasibly and comfortably as someone with no visual and print disability.

However, certain accessible formats that facilitate access can also be used by people without disability. E.g., audiobooks not only assist people with visual and print disability to access printed works, but may also be enjoyed by people without disability if they prefer to listen to a book instead of reading one. If audiobooks are excluded from the accessible formats under copyright exceptions simply because they can also be used by individuals without disability, a large number of disabled individuals will suffer from the decision. In order to strike the balance between the interests of copyright holders and beneficiary persons, two approaches can be recommended. First, these accessible format copies shall be restricted in volume to be available only to the beneficiary persons. Second, if the overall volume of accessible format copies is not restricted, the producers or distributors are required to compensate copyright owners.

\section{Authorized Entity}

According to the Marrakesh Treaty, entities are permitted to produce and distribute accessible format copies defined as those authorized or recognized by the government to provide information-access services for beneficiaries on a nonprofit basis. ${ }^{58}$ Although copyright exceptions are stipulated for the blind, Chinese Copyright Law does not specify authorized entities that can transliterate published works into Braille. It seems that any entity is free to produce Braille works for the blind as long as it satisfies the three-step test in this course. However, due to the high costs and complex production process for Braille works, not many entities can produce Braille or transliterate published works into Braille in China. 
Currently, among more than 500 publishing houses in China, only China Braille Press is capable of publishing works in Braille. ${ }^{59}$ In collaboration with China Braille Press, China Braille Library produces and stores works in Braille and provides lending, education and training services for the blind. ${ }^{60}$ Therefore, China Braille Library meets the definition of an authorized entity as stipulated in Article 2(c) of the Marrakesh Treaty.

Chinese copyright laws and regulations could encounter two problems without the definition of authorized entities. First, the production of accessible format copies can be carried out by any entity, which will negatively affect the interest of copyright owners. Since there is a significant potential market for audiobooks and large print due to the increase of aging population who have failing sight, entities would have incentive to produce accessible format copies to meet their needs. ${ }^{61}$ This production may not be carried out by the original copyright owners, but thirdparty publishers. An exception for the commercial publications will therefore conflict with the normal exploitation of copyright owners of their works, even if those are carried out for the benefit of the disabled. Second, without clarifying the qualification of an entity that is allowed to produce copies in an accessible format, only a few publishers or organizations will make it available. Therefore, it is recommended that certain entities be granted the authority to make and distribute accessible format copies in both the printed and digital world.

China has established the China Disabled Persons' Federation and China Association of the Blind under the Ministry of Civil Affairs. The National Copyright Administration of China ("NCAC") is established to protect copyright and manage copyright collective societies. The Ministry of Civil Affairs and NCAC could collaborate to authorize entities in the production and distribution accessible format copies for people with visual and print disability. It is important to define 'authorized entity' in the Chinese Copyright Law as one that is authorized and recognized by the Ministry of Civil Affairs and NCAC to provide education, instructive training, adaptive reading or information access to beneficiary persons on a non-profit basis. ${ }^{62}$ Authorized entities should also include government institutions and non-profit organizations with primary activities or institutional obligations to provide the same services for beneficiary persons, such as the China Blind Library, China Association of the Blind, and China Disabled Persons' Federation. Furthermore, a set of detailed and feasible regulations and 
practice guidelines should be established to ensure the effective operation of the authorized entities.

\section{Works under Copyright Exceptions}

The Marrakesh Treaty lists literary and artistic works in text, notation and/ or illustration format for the purposes of copyright exceptions. Although the Chinese Copyright Law does not clarify the categories of published works that can be transliterated into Braille, since Braille comprises patterned dots in convex and concave formats, ${ }^{63}$ only works in text, notation and/or illustration format are eligible for transliteration into Braille. Under the Regulation, ${ }^{64}$ only literary works are permitted to be converted into a specific format perceptible to the blind. Therefore, the categories under the exceptions for the blind in Chinese copyright laws and regulations are consistent with those in the Marrakesh Treaty.

Nevertheless, works defined in the Chinese Copyright Law are broader than literary and artistic works. They include written works, oral works, musical, dramatic, quyi 曲艺, ${ }^{65}$ choreographic and acrobatic works, works of fine arts and architecture, photographic works, cinematographic works and works created by a process analogous to cinematography, graphic works such as drawing of engineering designs and product designs, maps and sketches, and model works, computer software, and other works as stipulated in laws and administrative regulations. $^{66}$

Among the list, the following are within the scope of literary and artistic works in text, notation and/or illustration format: written works, musical, dramatic, quyi, choreographic and acrobatic works, works of fine art, photographic works, graphic works, and computer software. Musical, dramatic, quyi, choreographic and acrobatic works refer to scripts or choreography presented by notes, words or special symbols, not stage performances. These works are in text, notation and/or illustration format. Computer software contains computer programs and documents which are also presented in the format of symbols, texts or illustrations. ${ }^{67}$

The rest are: (1) equally accessed by people with visual and print disability and by people without disability, such as oral works and mini model works, as disabled people can sense out mini model works through touching them; (2) due to their features, not able to be well appreciated by people with visual and print 
disability even when those works are converted into accessible format, such as architecture and large model works; and (3) debatable on whether they should be converted into accessible format, such as cinematographic works. "Other works as provided for in laws and administrative regulations" acts as a fallback provision, but there are no other kinds of works outside the list provided by other laws and regulations. $^{68}$

For (1) and (2), it is not necessary to provide copyright exceptions for beneficiary persons to access these works. For (3), however, exceptions should be introduced in the Chinese Copyright Law. In terms of cinematographic works, it is debatable whether they should be provided as exceptions for beneficiary persons, because developed and developing countries have different viewpoints. ${ }^{69}$ Here, it is argued that exceptions should be provided for cinematographic works in the Chinese Copyright Law. On the one hand, disabled people with visual impairment cannot fully enjoy cinematographic works by only listening to the soundtrack; on the other hand, when cinematographic works are converted into audio recordings with explanations, only beneficiary persons are likely to access the audio recordings since those who are not disabled will prefer watching the original version of the films.

Therefore, those works are permitted to be converted into such accessible format copies as written works, musical, dramatic, quyi, choreographic and acrobatic works, fine arts, photographic works, cinematographic works and works created by a process analogous to cinematography, graphic works, and computer software.

\section{E. Permitted Activities under Copyright Exceptions}

Four exclusive rights are covered by the copyright exceptions in the Marrakesh Treaty, namely, the rights of reproduction, distribution, making available to the public and public performance. ${ }^{70}$ Although Chinese copyright laws and regulations do not clarify exclusive rights under the copyright exceptions for the blind, considering the permitted transliteration of published works into Braille and publication of the work so transliterated, exclusive rights under the copyright exceptions should include the rights of reproduction and distribution. ${ }^{71}$ The Regulation extends the exception for the benefit of the blind to the digital environment, which permits the public to use the transliterated works in Braille. ${ }^{72}$ 
In light of permitted activities under Chinese copyright laws and regulations, the exceptions for beneficiary persons would comply with the Marrakesh Treaty. Since the defined beneficiary persons and range of accessible format copies in the Chinese Copyright Law is narrow, however, actual permitted activities do not parallel the intentions of the Marrakesh Treaty.

Article 10 of the Chinese Copyright Law provides a series of exclusive rights that protect the interests of copyright owners, ${ }^{73}$ among which the rights of rental, public performance, adaptation, translation and compilation fall under activities undertaken for the benefit of people with visual and print disability aside from the three exclusive rights. The right of rental is deemed as an extension of the right of reproduction and distribution. An exception for the rental rights should be provided for people with visual and print disability, under which authorized entities are able to rent cinematographic works and works created by a process analogous to cinematography, and computer software in accessible format to beneficiary persons.

An 'exception' for public performances is provided under Article 4(1)(b) of the Marrakesh Treaty, but has not yet been included in the Chinese Copyright Law. For consistency, China should provide an exception for the right of public performance in the Copyright Law which would therefore allow authorized entities to publicly perform works where beneficiary persons gather, such as schools and cultural associations, without the necessary authorization from the copyright owners. $^{74}$

The rights of adaptation and compilation concern abridging, simplifying, and adapting existing works to create new works. Since people with visual and print disability may receive different, often lesser education than individuals without disability, they may encounter difficulties in understanding the original works, such as literature masterpieces and academic monographs. Thus, facilitating the access to copyright works means abridging, simplifying and adapting the original works. $^{75}$ These can be achieved by providing exceptions for adaptation and compilation. Otherwise, authorized entities will need to obtain a license from the copyright owners to change the contents of their work, but authorized entities that operate on a non-profit basis often lack the capital and the resources to do so.

Whether translation should be included as an exception? Developed countries opined in the negotiation process of the Marrakesh Treaty that copyright exceptions 
should not provide beneficiary persons with better treatment. ${ }^{76}$ In China, individuals who are not disabled cannot read the Chinese translation of an English book unless publishers in China obtain a license for translation from the copyright holder in the English-speaking country, e.g., an exception for Chinese translation without authorization of the copyright holder should not be allowed. Therefore, developed countries are opposed to allow translation as an exception. Hence, providing exceptions regarding translations should generally not be allowed. According to the Appendix provisions of the Berne Convention for the Protection of Literary and Artistic Works, exception for the right of translation shall be applicable to developing countries that are unable to arrange protection for such the right of translation. ${ }^{77}$ Although China is a developing country, it has provided protection for all the exclusive rights of copyright owners. Therefore, the right of translation shall not be applied in China.

Whether China should incorporate the commercial availability test into the Copyright Law so that accessible format works can only be produced where they "cannot be obtained commercially under reasonable terms for the beneficiary persons in that market"? ${ }^{78}$ The introduction of the commercial availability test is not essential at this moment for several reasons. First, it will be costly and time-consuming for authorized entities to conduct market investigations before producing accessible format copies. Second, the Marrakesh Treaty does not elaborate on 'reasonable terms.' Therefore, it is unclear whether the subjects who are unable to commercially obtain accessible format works in the market refer to the majority of people with visual and print disability or particular individuals who require access to information. ${ }^{79}$ There is also a lack of clarity on the reasonability of the terms. Therefore, China should not introduce the commercial availability test without examining the transaction costs for authorized entities or beneficiary persons in conducting market investigations.

\section{F. Export and Import of Accessible Format Works}

One of the major breakthroughs of the Marrakesh Treaty is to facilitate the access of copyright works to the visually impaired and people with print disability by providing exceptions for the cross-border exchange of accessible format copies. The Chinese Copyright Law does not address the cross-border exchange at all, so that lawmakers should consider incorporating exceptions for export and import of 
accessible format works in domestic legislations. As a result, VIPs in China may access books in languages other than in Chinese, and VIPs who are Chinese and living abroad may have access to publications in Chinese.

In order to maintain the balance of interests between copyright owners and beneficiary persons in different countries, it is recommended that the Chinese Copyright Law stipulate that accessible formats produced by Chinese authorized entities can only be exported to countries that have ratified the Marrakesh Treaty, and provide exceptions for cross-border exchange in their domestic laws. Accessible formats imported from other countries thus will only be distributed and made available to beneficiary persons in China.

Furthermore, relevant government organs in China, such as the Ministry of Civil Affairs and NCAC, should encourage voluntary sharing of information among authorized entities, ask for assistance from authorized entities to establish policies and practices, as well as make available the information about the policies and practices. The PRC government may also wish to collaborate internationally with other contracting parties of the Marrakesh Treaty to promote cross-border exchange of accessible format works.

\section{G. Circumvention of Technological Measures}

As a member country of WCT, China implemented an anti-circumvention rule into its domestic copyright law to protect technological measures. Article 4 of the Regulation stipulates:

No organization or individual may purposely avoid or break the technological measures, purposely manufacture, import or provide to the general public any device or component that is mainly applied to avoiding or breaking the technological measures, or purposely provide such technological services to any other person for the purpose of avoiding or breaking the technological measures, unless it is otherwise provided for by any law or regulation that the relevant technological measures can be avoided.

'Technological measures' are generally defined by the Regulation as:

the effective techniques, devices and components that are applied to preventing or restricting the browse or appreciation of the works, performance and audio-visual 
products in the absence of the relevant owner's permission or in providing the work, performance and audio-visual products to the general public through the information network in the absence of the relevant owner's permission. ${ }^{80}$

The definition and description of 'technological measures' are quite vague in Chinese law, as they do not clearly indicate whether these measures are used for access-control or copy-control. Phrases such as 'browse,' 'appreciation' and "provides ... to the general public through the information network" used in the definition show that the technological measures in the Chinese law refer to both those that control access, and copying of the protected works. ${ }^{81}$ In addition, Chinese law does not specifically differentiate the circumvention act from the trafficking of circumvention-enabling devices. According to the anticircumvention provision, Chinese law prohibits the circumvention of both accesscontrol and copy-control measures as well as the trafficking of devices that facilitate the circumvention of both access-control and copy-control measures. ${ }^{82}$

The Regulation ensures that public interests are not violated with four specific exceptions that apply to the circumvention act only (not to the trafficking of circumvention devices). These four exceptions are teaching and scientific research, provision of works for the blind, enforcement of governmental official duties, and security testing. ${ }^{83}$

Although Chinese law has introduced an exception for the circumvention of technological measures for the purpose of supplying published literary works in a specific way perceptible to the blind through the information network, this exception has limitations and does not meet the objectives set forth by the Marrakesh Treaty. First, similar to the other exceptions that benefit the blind in the Chinese Copyright Law and its regulations, the defined scope of beneficiary persons and accessible format works in the exception for circumvention is narrow, only including the blind and format perceptible to the blind, such as Braille. Second, the exception only allows works to be offered though the information network. In other words, the circumvention of technological measures for distributing the accessible format works offline, is prohibited. Third, the exception for the circumvention under the Regulation further includes that a circumvented protected work should only be made available through the information network. ${ }^{84}$ However, works protected by technological measures are not only made available 
online, but also in the form of compact discs or e-readers. In compliance with the statutory exception, circumvention of technological measures used to protect works stored on compact discs or e-readers will also be prohibited. ${ }^{85}$ Finally, the exception does not extend to the trafficking of circumvention devices, but only applies to the circumvention act itself. ${ }^{86}$ Under such circumstances, only people or entities with adequate knowledge or skills to carry out circumvention are actually able to benefit from the exception.

Considering these problems, it is proposed that when the exceptions for circumvention of technological measures are revised, lawmakers should well consider the following issues: (1) increasing the defined scope of beneficiary persons and accessible format copies to parallel the general exceptions; (2) removing the restriction in which protected works are only available from and made available through the information network; and (3) allowing production and distribution of circumvention devices to authorized entities that aim to implement technological measures for the production and distribution of accessible format copies for those with visual and print disability. A set of detailed practices could be established that assist authorized entities to lawfully acquire circumvention devices.

\section{Conclusion}

The adoption of the Marrakesh Treaty is a significant step toward facilitating access for the blind, visually impaired individuals, and people with reading and print disability to copyrighted works. The Marrakesh Treaty is the first international copyright agreement that specifically addresses copyright limitations and exceptions. As a signatory to the treaty, China would ratify it in the near future. Thus, it is important for lawmakers in China to consider implementing the treaty provisions into Chinese copyright laws and regulations prior to its ratification. In the implementation process, a number of issues, including the definition of beneficiary persons, accessible format copies, authorized entities and works covered by the exceptions should be provided. Permitted activities within both China and across national borders should be elaborated. Lawmakers in China may consider two approaches to implement the provisions of the Marrakesh 
Treaty: to either directly incorporate the provisions into the Chinese Copyright Law, or promulgate an independent copyright regulation that specifically governs exceptions for people with visual and print disability.

Additionally, providing statutory copyright exceptions for those with visual and print disability does not exclude other possible approaches to facilitate their access to copyright works. Copyright collecting societies ${ }^{87}$ in China may help copyright owners license their works for transliteration into accessible formats benefitting people with visual and print disability. A licensing scheme could be established specifically for the access of copyright works by beneficiary persons. Public libraries in China, especially the National Library of China and libraries at the provincial level could maintain, and lend works in accessible formats for people with visual and print disability while collaborating with publishers. By merging statutory exceptions with alternative approaches, facilitating the access of copyright works to individuals with visual and print disability is certain to be realized.

\section{REFERENCES}

1. WHO, Visually Impaired and Blindness (Aug. 2014), available at http://www.who.int/ mediacentre/factsheets/fs282/en (last visited on Feb. 3, 2017).

2. WIPO, Limitations and Exceptions: Access to Books for the Visually Impaired- Background Brief (Jan. 2014), available at http://www.wipo.int/pressroom/en/briefs/limitations.html (last visited on Feb. 3, 2017).

3. J. Sullivan, Study on Copyright Limitations and Exceptions for the Visually Impaired (Feb. 2007), available at http://www.wipo.int/edocs/mdocs/copyright/en/sccr_15/sccr_15_7.pdf (last visited on Feb. 3, 2017).

4. S. Fitzpatrick, Setting Its Sights on the Marrakesh Treaty: the U.S. Role in Alleviating the Book Famine for Persons with Print Disabilities, 37 B.C. InT'L \& Comp. L. Rev. 139 (2014).

5. WIPO, Marrakesh Treaty to Facilitate Access to Published Works for Persons Who Are Blind, Visually Impaired, or Otherwise Print Disabled (June 2013), available at http://www. wipo.int/treaties/en/ip/marrakesh (last visited on Feb. 3, 2017).

6. Bookshare, Who We Are, available at https://www.bookshare.org/cms/about (last visited on Feb. 3, 2017).

7. WIPO Copyright Treaty art 11.

8. The US Copyright Act of 1976, §1201; The EU Copyright Directive 2001/29, art. 6; The PRC 
Regulation on the Protection of the Right to Network Dissemination of Information, arts. 4 \& 26.

9. The US Copyright Act, §1201; The EU Copyright Directive 2001/29, art. 6(4); The PRC Regulation on the Protection of the Right to Network Dissemination of Information, art. 12.

10. C. Tan, Moving Towards A More Inclusive Copyright Regime for the Visually Impaired, 24 Sing. Academy L. J. 433 (2012).

11. Id.

12. F. Calvo, Technological Advances Benefiting Visually Impaired People (Nov. 2003),

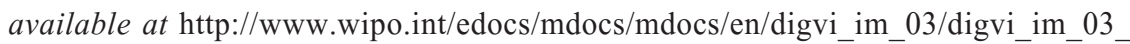
francisco_mart_nez_calvo.pdf (last visited on Feb. 3, 2017).

13. TRIPS Agreement art 13.

14. Panel Report, United States Section 110(5) of the US Copyright Act, WTO Doc. WT/DS160/ $\mathrm{R}$ (adopted on June 15, 2000), $\uparrow 6.108$, available at https://docs.wto.org/dol2fe/Pages/FE_ Search/FE_S_S009-DP.aspx?language=E\&CatalogueIdList=55222\&CurrentCatalogueIdIn dex $=0 \&$ FullTextHash $=$ (last visited on Feb. 3, 2017).

15. Id.

16. Supra note 10.

17. Id.

18. Interpretation of the People's Republic of China Supreme People's Court on Several Issues about Application of the Contract Law (II), art. 14; Guiding Opinions on Several Issues in the Trial of Civil and Commercial Contract Disputes Cases under the Current Situation of the People's Republic of China Supreme People's Court, art. 15.

19. Marrakesh Treaty arts. 5-6.

20. Id. footnote 3 .

21. Id. art. 2(b).

22. M. Fiscor, Commentary to the Marrakesh Treaty on Accessible Format Copies for the Visually Impaired (Oct. 11, 2013), available at http://www.copyrightseesaw.net/data/ documents/documents/d/1/2/d12ec5c8382563487dbc7602a0ceb27c.doc (last visited on Feb. 3, 2017).

23. Marrakesh Treaty art. 4(1)(a).

24. Id. art. 2(c).

25. Id. footnote 2 .

26. J. Band, A User Guide to the Marrakesh Treaty (Aug. 13, 2013), available at http://www. llrx.com/2013/08/a-user-guide-to-the-marrakesh-treaty (last visited on Feb. 3, 2017).

27. Marrakesh Treaty art. 2(c).

28. Id. art. 2(a).

29. Id. footnote 1 .

30. Qian Wang, Discussion on the Marrakesh Treaty and Its Influence to the Copyright Legislations of China 论《马拉喀什条约》及对我国著作权立法的影响 363 L. SCI. 法学 51 
(2013).

31. Id.

32. Ministry of Business, Innovation \& Employment of New Zealand, Discussion DocumentMarrakesh Treaty: Possible Accession and Options for Implementation (Oct. 2015), available at http://www.mbie.govt.nz/info-services/business/intellectual-property/copyright/ marrakesh-treaty/consultation/discussion-document.pdf (last visited on Feb. 3, 2017).

33. Id.

34. Marrakesh Treaty art 4(4). It provides: “A Contracting Party may confine limitations or exceptions under this Article to works which, in the particular accessible format, cannot be obtained commercially under reasonable terms for beneficiary persons in that market. Any Contracting Party availing itself of this possibility shall so declare in a notification deposited with the Director General of WIPO at the time of ratification of, acceptance of or accession to this Treaty or at any time thereafter."

35. University of Cape Town Intellectual Property Unit, Marrakesh Treaty Implementation Guide South Africa (May 2015), available at http://ip-unit.org/wp-content/uploads/2015/05/ IPUnit_MarrakeshGuideSA1.pdf(last visited on Feb. 3, 2017).

36. Id.

37. Marrakesh Treaty art. 4(3). It provides: "A Contracting Party may fulfill Article 4(1) by providing other limitations or exceptions in its national copyright law pursuant to Articles 10 and 11."

38. WIPO, Standing Committee on Copyright and Related Rights, SCCR/24/12 (July 16-25, 2012), ๆๆ 420 \& 424-425, available at http://www.wipo.int/edocs/mdocs/copyright/en/ sccr_24/sccr_24_12.pdf (last visited on Feb. 3, 2017).

39. Id. $\Upsilon 424$.

40. Id. art. 4(2)(a).

41. Id. art. 4(2)(b).

42. Id. art. 4(5).

43. Id. art. 5(1)\&(2).

44. Id. footnote 7 .

45. Id. art. 5(3).

46. Id. footnote 10. It provides: "It is understood that the Contracting Parties have the same flexibilities set out in Article 4 when implementing their obligations under Article 6."

47. Id. art. 7.

48. Id.

49. Id.

50. $I d$. footnote 11 . It provides: "It is understood that authorized entities, in various circumstances, choose to apply technological measures in the making, distribution and making available for accessible format copies and nothing herein disturbs such practices when in accordance with national law." 
51. PRC Copyright Law art. 22(12).

52. Implementing Regulation of PRC Copyright Law, art. 21.

53. The Regulation art. 6(6).

54. Marrakesh Treaty art. 3.

55. Id.

56. Id. art 2(2).

57. Jianhua Zhang (ed.), Explanations on Regulation on the Protection of the Right to Network Dissemination OF InFormation 信息网络传播权保护条例释义 28 (Beijing: China Legal Publishing House, 2006).

58. Marrakesh Treaty art. 2(c).

59. Na Li, Problem Analysis and Strategy Discussion about Braille Publishing in China 我国盲 文出版的问题分析与对策探讨, 7 VIEW ON PUBLISHING 出版广角 96 (2015).

60. China Braille Press and China Braille Library, available at http://www.blc.org.cn/EN/ AboutUs.aspx (last visited on Feb. 3, 2017).

61. Supra note 30.

62. Marrakesh Treaty art. 2(c).

63. Supra note 57.

64. The Regulation art. 6(6).

65. Quyi is a kind of traditional Chinese performance of art, including narrative and musical performance.

66. PRC Copyright Law art 3.

67. Legislative Affairs Office of the State Council (ed.), PRC Intellectual Property Law Code 国 务院法制办公室编 中华人民共和国知识产权法典 (2014).

68. Id.

69. Supra note 38.

70. Marrakesh Treaty art. 4.

71. PRC Copyright Law art. 22(12).

72. The Regulation art. 6(6).

73. Article 10 provides 17 exclusive rights. The first four kinds of rights are deemed as 'moral' rights and the last 13 kinds of rights are deemed as 'economic' rights.

74. Supra note 30.

75. Id.

76. Supra note 38.

77. Berne Convention for the Protection of Literary and Artistic Works, App'x, arts. I (1) \& II(2)(a).

78. Marrakesh Treaty art. 4(4).

79. Supra note 32.

80. The Regulation art. $26, \boldsymbol{q} 2$.

81. Id. 
82. Id. art. 4.

83. Id. art. 12.

84. Supra note 30.

85. The Regulation art. 4.

86. Id. art. 12.

87. There are five copyright collecting societies in China: (1) Music Copyright Society of China; (2) China Audio-Video Copyright Association; (3) China Written Works Copyright Society; (4) Images Copyright Society of China; and (5) China Film Copyright Association (Collective). 